\title{
KARL MARX'TA BÖLÜŞÜM
}

Volkan TURAN 1

\section{Özet}

$\mathrm{Bu}$ çalışmada, iktisadın temel konularından olan "bölüşüm” meselesi, Karl Marx'ın bölüşümle ilgili teori ve görüşleri 1şığında, Kamu Yönetiminin temel inceleme alanlarında yer alan yoksulluk, geçinme stratejileri, göç, rantların kamuya aktarılması, kentleşme, yatırım, kamu mali yönetimi, ekonomik-politik araştırmalar gibi alanlarda sosyalist-kapitalist bakış açısıyla yapılacak bilimsel çözümlemeler için alt yapı oluşturulacaktır.

$\mathrm{Bu}$ çalışma hazırlanırken öncelikli olarak, Marx’ın çalışmaları temel alınarak konu anlatılmaya çalışılmıştır. Ardından diğer kaynaklara başvurulmuştur.

Giriş bölümünde, Marx'ın genel teorisine ilişkin çıkarımlar bulunmaktadır. Teorinin ana çerçevesi içinde makale konusunun yeri tespit edilmiştir. Birinci bölümde, bölüşüm meselesinin belirleyicisi olan "Emek Değer Teorisi”, “Artık Değerin” nasıl oluştuğu, kaynağı ve bu artığın sınıflar arası nasıl paylaşıldığına değinilmiştir.

İkinci bölümde, "Emek Değer Teorisinin” açıklanmasını desteklemek amacı ile “Toplumsal Olarak Gerekli Emek Zaman” aktarılmış, değerin temelinde yatan etmenler araştırılmıştır. Üçüncü bölümde kapitalist sınıfa kâr biçiminde geçen “Artık Değerin”, kapitalist sınıf içinde bölüşümünün nasıl gerçekleştiği açıklanmıştır. Dördüncü bölümde, Komünizmde ve geçiş sürecinde, bölüşümün dayandırıldığ 1 prensipler aktarılmıştır.

Anahtar Kelimeler: Karl Marx, Emek Değer Teorisi, Artık Değer, Tarihsel Kurumsal Yapılar, Sınıf Çatışması, Rantların Kamuya Aktarılması, Ekonomi-Politik.

\footnotetext{
${ }^{1}$ Yrd.Doç.Dr., Uşak Üniversitesi, Sosyal Bilimler Meslek Yüksekokulu, volkan.turan@usak.edu.tr
} 


\title{
DISTRIBUTION AND KARL MARX
}

\begin{abstract}
In this paper, an infrastructure will be established for scientific analyses which will be carried out with an socialist-capitalist perspective in such fields as poverty, livelihood strategies, migration, transferring the incomes to the public, urbanization, investment, public finance management, economic and politic researches which are among the main research areas of Public Administration, in the light of 'Distribution' issue which is one the main subjects of Economics and Karl Marx's theories and views about Distribution.
\end{abstract}

In the preparation process of this paper, Marx's studies have formed the basis for covering the topics primarily. After that, it has also been benefited from other resources.

In the Introduction, some inferences related to the general theory of Marx have been taking place. The position of the article's subject has been decided within the main framework of the theory. In the first part, 'Labor Theory of Value' which is the determiner of Distribution issue, the formation and the resource of 'Surplus Value' and the sharing of the surplus among the classes have been mentioned.

In the second part, 'The Required Labor and Time as a Society' has been cited and the factors which set the basis for the value have been researched with the aim of supporting the explanation of 'Labor Theory of Value'. In the third part, it has been explained that how the 'Surplus Value', which is transferred to the capitalist class as profit, is shared within that class. In the fourth part, the principles, which Distribution has been based on, have been explained in Communism and Transitional Period.

Keywords: Karl Marx, Labor Theory of Value, Surplus Value, Historical Institutional Structures, Class Conflict, Transferring the Incomes to the Public, EconomicPolitic. 


\section{Giriş}

Karl Marx'ın teorisinde üç temel girdi söz konusudur. Bunların ilki üretici güçler ve bunların değişimidir. İkincisi, ideolojik üst yap1, ki bu hükümet, kanun, politika, din, sanat, edebiyat ve felsefe bilimi gibi tarihsel, kurumsal yapıları kapsar. Üçüncüsü ise üretimin yapılış biçimi, yani üretim tarzıdır. $\mathrm{Bu}$ ekonomik sistem olarak da adlandırılabilinir. Ekonomik sistem içinde Marx'ın altını çizdiği en önemli konu, sınıflar arasındaki güç ilişkisidir. Bölüşüm ilişkilerinden bahsedebilmek için ekonominin artık üreten bir ekonomi olması gereklidir. Bu makalenin konusu olan bölüşüm ilişkileri de üretim tarzı ile belirlenmekte ve sınıflar arası güç ilişkilerinin etkileşimi içine girmektedir.

Marx'1n tarihsel temellere dayanan ve kapitalizmi analiz eden teorisini, kısaca özetlenecek olursak; Teoriye göre üretim güçleri değiştiği zaman, üretimin üretim tarzı da değişir. Çünkü her yeni ve birbirinden farklı üretim gücü ilişkisi için ona uygun benzersiz bir takım sınıf ilişkisi söz konusudur. Bu nedenle her üretim gücü ilişkisi, sınıflar arasında bu ilişkiye özgü bir güç dağılımının varlığını ortaya çıkaracaktır. Bu güç dağılımı ve sınıf ilişkileri tarihsel ve toplumsal veriler altında bölüşümü şekillendirecektir.

Ancak üretim tarzının değişimi, var olan üstyapı tarafından hoş karşılanmaz ve buna karşı bir direniş söz konusu olur. Üretim güçleri değiştiği zaman üretim tarzının da değişmiş olması gerekir, fakat var olan ve üst yapı üstünde etkin olan güçler üretim tarzının değişikliğine karşı çıkmaya çalışırlar. Bunlar ise baskın grubun güçten düşmemek için yaptı̆̆ çabalardır.

Üretim güçleri değişmeye devam ettiği sürece, sistemi elinde tutan güçler bu değişime karşı çıkar, yeni oluşan üretim güçleri de zaman içinde güçlenecektir. Sonunda üretim güçleri yeteri kadar güçlendiklerinde, toplumsal üstyapıyı değiştirmek için devrim yaparlar. Bu sayede yeni üretim tarzının gerektirdiği değişikliği yapabilirler. Baskın sınıfın bu gelişmeye geçici bir süre içinde olsa karşı çıkmasına rağmen sonunda değişim, devrimi gerçekleştirebilir.

Üretim tarzının bir sonucu olarak ortaya çıkan ve devrime yol açan yeni üretici güçler, toplumu bir sınıf eşitsizliğinden başka bir sınıf eşitsizliğine taşıyabileceği gibi, sınıfa dayalı eşitsizlikten sınıfsız bir topluma da taşıyabilir. Birinci durumda değişim süreci devam ederken, üretim güçleri tekrar değiştiğinde yeni bir üretim tarzına yol açacak bir devrim ortaya çıkacaktır. Fakat ikinci durumda, yeni doğan üretim tarzı, sınıfsız bir 
toplumsa, devamlı değişim yapısı sona erecektir. Gelecekteki üretim güçlerindeki değişim üretim şeklinin değişmesine neden olmayacaktır.

Marx'ın analizinde, kapitalist sistemde “bölüşümü” iki ayrı eksende düşünmek mümkündür. Bunlardan ilki üretim süreci sırasında değer yaratma aşamasında ortaya çıkan artık değerin oluşumu ve el konulmasını analiz eden sınıflar arasındaki bölüşümdür ve "emek değer teorisi” ile açıklığa kavuşturulur. İkincisi ise bölüşümün dolaşım sırasında, kapitalist sınıf içindeki paylaşımının analizidir. Bu kısaca artık değerden doğan kârın kapitalistler arasındaki paylaşımıdır. Her ne kadar böyle bir ayrım konuyu kolay aktarabilmek amacıyla yapılabilirse de önemli olan, bölüşümün ve bu her iki süreci de belirleyen etmenin üretim süreci olduğu, bölüşümün üretim sırasında belirlendiğidir.

Klasik politik ekonomi bölüşüm teorisini, değişim teorisinden ayrı ele almaktadır. Marx serveti, kullanım değeri yerine emeğe bağlamıştır. Bu sayede tekniğin neden olduğu üretimde görülen birbirine bağımlı ilişkileri göz önüne almıştır. Böylece Marx tüm bu ilişkileri piyasa sisteminin dışında ve piyasa sisteminden bağımsız olarak incelemiştir.

\section{Emek Değer Teorisi ve Artığın Sınıflar Arası Bölüşümü}

Bu bölümde Marx'ın emek değer teorisi temel alınarak artığın ortaya çıkışı ve işçi sınıfı ile kapitalistler arasındaki bölüşümü ele alınmıştır. Marx'ın emek değer teorisinde odaklandığ temel nokta, kapitalist üretim ilişkileri çerçevesinde, ortaya çıkan artığın kaynağı ve sınıflar arası bölüşüm yasalarıdır. Artığın sınıf içi bölüşümü yada kapitalistler arası bölüşümü Marx tarafından dışlanmamakla beraber temel dinamiğin işçi ve kapitalist arasında gerçekleşen etkileşimlerin olduğu önemle belirtilmiştir.

"Marx temelde toprak ve rant üzerinde durulmasını kabul etse de, bunu yanıltıcı bulmuştur.... Bilhassa şu cümle çok önemlidir, "Sermaye burjuva toplumunda her şeye hükmeden yegane güçtür" düşünüşünün, klasik iktisatçılar için olduğu kadar Marx için de anlamı, temel iktisadi ilişkinin kapitalist ve işçi arasında ortaya çıktığıdır.’'(Swezzy, 2007: 28).

Marx emek değer teorisini kurarak, artık değer kavramına ulaşmaktadır. Bu yolla Marx'ın tasarımında, toplumda yaşanan mülkiyet, bölüşüm ve sınıf mücadelelerine ilişkin tüm olguları açıklamada, emek değer teorisi ve artık değer kavramı temel dayanak noktasını oluşturmaktadır. Bunun ötesinde Marx, emek değer teorisi ve artık değer ile kapitalist sisteme yönelik tarih boyunca yapılan en güçlü eleştiriyi yöneltmiştir. 
"Marx’ın sisteminin temel taşları onun değer anlayışı ve değer yasasıdır. Bunlar olmadan, Marks'ın birçok defa söylediği üzere, ekonomik gerçeklerin bütün bilimsel bilgisi olması olanaksızdr." (Hilferding, 1949: 9).

Marx, bölüşüm ve dolaşıma yönelik düşüncelerini bir potada eritmiştir. Marx’’n emek değer teorisine, emek zamanının bölüşümü teorisi olarak da bakılabilir. Marx değişime konu olan her malın değerinin harcanan insan emeği tarafından belirlendiğini belirtir ve bu emek üretken yani artık değer üreten emektir.

"Kapitalist üretim anlamında üretken emek, değişen sermaye parçasına (Sermayenin ücretle harcanan parçasına) karşılık değiştirilen ve sermayenin yalnızca bu parçasına (yada kendi emek gücünün değerini) değil ayrıca ona ek olarak kapitalist için bir artı değer üreten ücretli emektir (Marx, 1998: 142).

"Bunların üretimi sırasında, insan emek-gücü harcanmıştır, bunlarda insan emeği cisimleşmiştir. Hepsinde ortak olan bu toplumsal özün kristalleri olarak

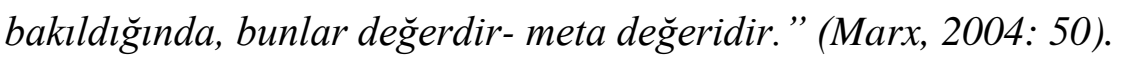

"Metaların değerleri, üretimlerinde kullanılan emek-zamanı ile doğru orantılı ve kullanılan emeğin üretken gücüyle ters orantılıdır." (Marx, 1992: 38).

Marx'ın teorisinde iki tip değer söz konusudur, kullanım değeri ve değişim değeri ayrıca bu iki değer arasında bir bağlantı bulunmamaktadır. Değişim değeri piyasa şartlarının oluşturduğu bir değerdir. Daha doğrusu ticari malların değişim ilişkileri kullanım değeri referans alınmadan belirlenir.

"Kullanım değerleri olarak, ticari mallar her şey bir tarafa farklı niteliktedirler; değişim değeri olarak, sadece miktar olarak farklıdırlar ve bu yüzden kullanım değerinin hiçbir birimini bünyesinde barındırmaz." (Hilferding, 1949: 10).

Kullanım değeri söz konusu olduğunda bir malın değeri tüketilen emek gücüyle sabitlenmiştir. Bu durum piyasanın dışında ya da dolaşıma girmeden önce gerçekleşen bir durumdur. Emeğin üretmek için harcadığı zamanın uzunluğu ise değerin belirleyicisidir. Sonuçta üretilen artık değerin büyüklüğü ise çalışma günü ile belirlenir. Kapitalizmin dinamikleri içinde artığa kapitalist sınıf tarafından el konulması ve sömürünün kaynağı ortaya konmuştur. Bu mekanizmayı Marx şu şekilde açıklar;

"Işş̧inin, emek-sürecinin bir kısmında yalnızca kendi emek-gücünün değerini, yani yaşaması için gerekli tüketim araçlarını ürettiğini görmüş bulunuyoruz... Emek gücünün 
bu yeniden üretimin yapıldiğı klsmına ben "gerekli emek-zamanı" ve bu sürede harcanan emeğe "gerekli emek" diyorum." (Marx, 2004: 215).

"Emek sürecinin, emeğinin artık gerekli olmadĭ̆ı ikinci dönemi boyunca da işçinin çalıştığl ve emek-gücü harcadiğl doğrudur, ama onun emeği artık gerekli-emek olmadı̆̆ından kendisi için bir değer yaratmaz. Bu dönemde, kapitalist için, hiç yoktan yaratmanın bütün güzelliklerini taşıyan “artı-değeri” yaratır. İsgücünün bu kısmına ben “artı-emek zamanı" ve bu zamanda harcanan emeğe "artı-emek” adını veriyorum." (Marx, 2004: 216).

Değer teorisinde, çalışma gününün uzunluğu ve bu yolla ele geçirilen artık emek zaman, sınıf mücadelesi ve bölüşüm açısından anlamlıdır. Sınıf mücadelesi sonucu artık emek zamanının uzunluğu ve dolayısı ile kapitalizm içinde, işçi sınıfı ve kapitalist sınıf arası bölüşüm ilişkileri temellendirilmektedir. Teori aynı zamanda emek gücünün sömürülme derecesini de belirler.

"Değer teorisinin görevi, bu üretim ilişkilerinin, sömürüye neden ve nasıl yol açtığını açıklamaktır... Marx için değer teorisinin önemi, mübadelenin arkasındaki sömürüyü görünür kllmasıdır." (Desai, 1977: 39).

Kapitalist sınıf tarafından işçi sınıfının yarattığı artığa el konulması yolu ile sömürünün gerçekleştirilmesi, mübadele öncesinde üretim sırasından gerçekleşir.

"Sınıf mücadelesi artık ürün için verilen mücadeleden başka bir şey değildir. Artık ürüne sahip olan durumun hakimidir; zenginliğe sahiptir, devlete sahiptir, kilisenin, mahkemenin, bilimin ve sanatın anahtarını elinde tutar." (Rühle, 2004: 19).

Artık değer ve emek gücü değeri arasındaki orana, Marx artık değer oranı demektedir. Bu oran aynı zamanda, artık emek zamanı ve gerekli emek zamanın oranına da eşittir. Marx'ın tasarımının içinde emek gücü üretimin tek girdisi değildir. Üretim yapmak ve emek gücünü tüketmek için aynı zamanda ham madde ve üretim araçlarına da ihtiyaç vardır. Bu girdiler değer içerirler ve bu değer de doğrudan ham madde ve üretim araçlarını üretmek için kullanılan gerekli emek miktarı ile belirlenir (Marx, 1992: 36).

Marx'a göre emek gücü olmadan makinelerin tek başına hiçbir değeri yoktur. Fakat emek gücü öyle değildir. Yapması gereken işe göre kendi makinesini üretebilir, sonuç olarak bütün iş emek gücü tarafından yapılmış olur. Buna karşın kapitalistler yani makinelerin sahibi olan sermaye sınıfı, kârın makinelerden geldiğine dair irrasyonel bir 
inançla devamlı olarak sermaye birikimine giderler. Bu onların harcamalarını artırırken kârlarını artırmaz çünkü artık değerin kaynağı emektir ve tek kâr sağlama aracıdır.

"Marx cansız emeğin aynı zamanda yeniden üretilmesine gerek olmadığını çünkü değerini zaten teknolojik ilerlemeden dolay yitirdiğini ve yerine koyma masrafinın aslında var olmadiğını belirtmektedir." (Perelman, 1999: 722).

Cansız emek içeren ham madde ve üretim araçları üretim sürecinde canlı emek yoluyla değerlerini son ürünün değerine aktarır ve yavaş yavaş eriyerek dönüşüm geçirip son ürüne akarlarken artık değer yaratmazlar. Sadece biçim değiştirirler, yaratılan artık değerin kaynağı canlı emektir.

“Metanın değerinin yalnızca hammaddelerin, makinelerin, tek sözcükle, tüketilen üretim araçlarının değerini temsil eden bölümü hiçbir gelir meydana getirmeyip, yalnızca sermayeyi yerine koyar." (Marx, 1992: 52).

Bir ürünün değeri, ham maddeler, üretim araçlarının değeri ve canlı emek tüketiminden yaratılmış yeni değerdir. Bu yolla, geçmişteki emek zaman da eklenerek, emek zaman ve değer arasındaki özdeşlik sürdürülür. Servetin, maliyet ve artık arasındaki bölüşümü temelde, zamanın bölüşümüdür (Marx, 2004: 216).

Üründe sabit olan, değer ve artık değerin belirlenmesiyle birlikte ürün, kendine özgü biçimde maliyetler ve artık arasında bölünmüştür. Beraberinde sistemin servetini bir bütün olarak, sermayenin geçmişte harcanmış ve bugüne transfer edilmiş emek zamanı biçiminde düşünmek de olasıdır. Toplumun bu serveti, kendi başına tamamen ücretler ve kârlar arasında bölünür. Çünkü nihai üretimin tek maliyeti, çeşitli zaman dilimlerinde harcanmış emekten ibarettir. Marx'ın teorisinde kârın, rant ve faizin kaynağı çok açık biçimde artı değerdir.

"Artı-değere, yani metaların toplam değerlerinin içinde artı-emeğin, yani işçinin ödenmemiş emeğinin gerçekleşmemiş bulunduğu bölümüne kâr adını veriyorum." (Marx, 1992: 51).

"Rant, faiz ve sınai kâr, metanın artı-değerinin, yani metanın içerdiği ödenmemiş emeğin çeşitli bölümlerine verilen farklı adlardan başka bir şey değildir ve hepsi de bu kaynaktan, yalnızca bu kaynaktan elde edilir." (Marx, 1992: 51).

Emek gücü değeri ve çalışma gününün uzunluğunun bilinmesi, servetin bölüşümünün belirlenmesi için yeterlidir. Sonuçta ortaya çıkan ürün, çalışanların 
kendilerini idame ettirmeleri ve kapitalistlerin tüketim ve yatırımı için bölüşülmüş olur. Artığın büyüklüğü ve kapitalistlerce el konması, bunu yanında artık ve çalışma gününün uzunluğu ile arasındaki ilişki, Marx'ın teorisinde sömürünün ve sınıf çatışmasının ortaya konmasında önemlidir (Desai, 1977: 50).

Marx'a göre kapitalist sistemde üretim süreci emeğin uzmanlaşması üstüne yapılandırılmıştır, bu noktada bölüşüm açısından değişimin önemi daha net görülür.

“[İş̧i]... tükettiği bu gerekli maddeleri doğrudan kendisi üretmez; o belli bir meta, diyelim ki iplik üretir ve bu ürünün değeri, bu gerekli maddelerin ya da bunlarl satın alabileceği paranın değerine eşittir. ” (Marx, 2004: 215).

$\mathrm{Bu}$ nedenle belirli bir çalışma sonucu yaratılan ürün, kullanım değerine dönüştürülür. Bu kullanım değeri, çalışanın kendini idame ettirebilmesi için gerekli emek zaman, ürünün ham madde ve üretim araçları gibi diğer girdilere dönüştürülmüş kısmı ve geri kalan da kapitalistlerin uygun gördüğü yerde kullandığı parçalardan oluşur.

Kullanım değerlerine dönüşümü etkilemek için, her bir tip özel emek gücü sahibinin, ürününü satmış olması gereklidir. Temelde bu satış, eşit miktarda emeğin değişimidir, yani belirli metada sabit emek miktarı ile evrensel eşitinin içerdiği emek zamanı arasında bir değişimi ifade eder.

Çalışanlar parasal bir ücret alırlar, bu işçinin kendini sürdürebilmesi için ancak yetecek kadardır. Artık ise kapitalistin gelecek dönemdeki üretim için, girdileri tekrar daha fazla satın almasına olanak tanır. Bu durum kapitalistin üretimi artırmasına ya da başka alanlara yatırım yapmasına olanak tanır.

Parasal büyüklüklerin bölüşümü, üretim süreci içinde belirlenmiş emek zamanının bölüşümü ile paraleldir. Üretimdeki uzmanlaşma, değişimin, bölüşümü etkilemesine neden olurken, ürünün boyutları ve onun bölüşümü, değişim tarafından etkilenmez. Değişim, önceden belirlenmiş bölüşümün bir mekanizması olarak görünmektedir. Marx çözümlemesinde kapitalist sistemde üretim sürecinde belirlenen bölüşümü açığa çıkarır.

“Marx'ın en önemli iddialarından biri şudur; Eğer çözümleme dolaşım veya değişim alanı ile sinırlı kalırsa ve üretim alanını ihmal ederse, kapitalizmin en önemli özelliklerinden bazllarl gizli kalır. "(Saad-Filho, 2002: 33). 
$\mathrm{Bu}$ bakış açısı altında Marx’ta emek değerlerinin, üretim fiyatlarına dönüştürülmesi de başka bir biçimde görülebilir. Marx metaların değişiminin emek değeri ile gerçekleştiği saptamasının bazı şartlar altında değişebileceğini de belirtmiştir.

Emek değerine göre gerçekleştirilen değişim, sermayenin farklı organik kompozisyonlarından kaynaklanan, sanayiciler için eşit olmayan kâr hadleri ortaya çıkarmaktadır. Emek değerlerinin bu eksikliğini ortadan kaldırmak için Marx, yeni bir takım mübadele değerleriyle sermaye üzerinde standart kâr hadlerine izin veren bir varsayım yapmaktadır. Kullanılacak sermaye üzerinde standart kâr hadlerine izin vermekte, bunu da sermayenin sabit ve değişken bileşenlerinden bağımsız olarak yapmaktadır. Bu yeni mübadele oranları, üretim fiyatlarına karşılık gelir, emek değerinin hesaplanmasında belirlenen, artık değeri verilmiş olarak alır ve bunu yalnızca sanayici kapitalistler arasında yeniden bölüştürür. Böylece her bir sanayici kapitalist sermayesi üzerinden standart bir oranda getiri sağlar.

Bu noktada Marx'ın analizi, ortaya çıkan artığın yeniden bölüşülmesini inceler. Gerekli ve artık emek arasındaki ayrımın altını çizer ve artığın bölüşümü için bir kural ortaya koyar. Artık, piyasa sisteminin ve kapitalist üretim tarzının bir gerekliliğidir. Beraberinde üretim fiyatlarındaki değişiklikler, artık değerlerin bazı sektörlerden diğerlerine doğru hareketini de sağlar.

Marx'1n teorisinde değer ve artık değer üretimde sabittir. Mübadele oranları, emek değerleri yada üretim fiyatları sadece bölüşümü etkiler. Bölüşümün belirlenmesi de değişim şartlarından tamamıyla bağımsız bir biçimde gerçekleşir. Bu nedenle Marx'ın dönüşümünde üretim fiyatlarıyla yeniden dağıtılan artık, emek zamanı ile hesaplanan artıkla özdeştir. Marx'ın kurduğu değer teorisini Marx'ın sözleri ile şu şekilde tekrar aktarmak mümkündür;

“Onun değerini, göreli değerinin büyüklü̆̆̈̈, içinde taşıdı̆̆ bu toplumsal özün az ya da çok oluşuna, yani üretim için zorunlu olan emeğin göreli miktarına bağlıdır. Metaların göreli değerleri, demek ki, her birinde kullanılmış, gerçekleşmiş, belirlenmişi emek nicelikleri ya da toplamlart ile belirlenir.” (Marx, 1992: 33).

“... metaların değerlerinin içerdikleri göreli emek miktarları ile belirlenmesi, metaların değerlerinin emeğin değeri ile, ya da ücretlerle belirlenmesi biçimindeki totolojik yöntemden bambaşka bir şeydir. ” (Marx, 1992: 35). 
Emek değer teorisinin güçlü yapısı, piyasa etkileşimlerinden bağımsız ve piyasa etkileşimlerinin önünde, önce gerçekleşen ve toplumsal ilişkilere dayalı servetin üretimini açıklayabilir.

\section{Toplumsal Olarak Gerekli Emek Zamanı}

Toplumsal olarak gerekli emek zaman, emeğin toplumsal olması özelliğiyle bağlantılıdır. Marx toplumsal olarak gerekli emeği bütün mallardaki ortak "şey” olarak tanımlamaktadır. Marx, bir malın değerini, toplumun teknolojik ve sosyal olarak içinde bulunduğu şartları göz önüne alarak belirler. Marx değerin temelinde yer almasının doğru olduğunu düşündüğü "toplumsal olarak gerekli emek" miktarı, eldeki teknik araçların ve sosyal düzenlemelerin bir ürünü olarak değişmektedir. Artık değer dediğimiz de bu toplumsal olarak gerekli miktarın üzerinde emeğin çalıştırılması sonucu ortaya çıkan artık emek ile meydana gelir.

Toplumsal etmenler emek üzerinde etkilidir ve emeğin toplusallaşması onu diğer metaların değerinden de ayırır, bu durum Marx tarafından şu şekilde açıklanmıştır;

“Ama bazı belirli özelikler vardır ki, emek gücünün değerini, yani emeğin değerini bütün öteki metaların değerinden ayırt ederler. Emek-gücünün değeri, biri salt fiziksel, ötekisi ise tarihsel ya da toplumsal olan iki öğeden oluşur. Emek-gücü değerinin en uç sınırı fiziksel öğe belirler, yani bu demektir ki, işçi sınıfının, geçinmesi ve yeniden üremesi, fiziksel varlığını sürdürmesi için, yaşamak ve çoğalmak için vazgeçilmez olan geçim araçlarını alması gerekir.” (Marx, 1992: 65-66).

"Salt fizyolojik olan bu öğe yanında, her ülkede, emeğin değeri, geleneksel yaşam düzeyi ile de belirlenir. Bir yaşam düzeyi, yalnız fiziksel yaşamdan ibaret olmayıp, insanların içinde yaşadıkları ve içinde yetiştirilmiş oldukları toplumsal koşullardan doğan bazı gereksinimlerin doyurulmasıdır." (Marx, 1992: 66).

"Emeğin değerine giren bu tarihsel ya da toplumsal öğe artabilir ya da azalabilir, büsbütün ortadan kalkabilir, öyle ki, fiziksel sınırdan başka bir şey kalmaz." (Marx, 1992: 66).

Toplumsal emek Marx'ın teorisi içinde değerin belirleyicisi rolündedir ve emek toplumsal iş bölümünün bir parçasıdır. Bu durum Marx tarafından şu şekilde açıklanmıştır;

"Metaların değişim değerleri, bu nesnelerin toplumsal işlevlerinden başka bir şey olmadığından ve değişim-değerlerinin metaların doğal nitelikleriyle ortak hiçbir yanı 
bulunmadı̆̆ından, ilkin şunu sormalıyı: bütün metaların ortak toplumsal özü nedir? Emektir.... Ama yalnızca emek demiyorum, toplumsal emek diyorum. Doğrudan kişisel kullanım için bir nesne üreten bir insan, bir ürün yaratır, ama bir meta yaratmaz. Kendi kendine yeten üretken olarak toplumla ortak hiçbir şeyi yoktur. Ama bir meta üretmek için, bu adamın yalnızca herhangi bir toplumsal gereksinimi karşllayacak bir şey üretmesi değil, kendi emeğinin de, toplum tarafindan harcanan toplam emeğin bir öğesi ya da bir parçası olması gerekir. Emeğin, toplum içindeki işbölümüne bağımlı olması gerekir. Öteki işbölümleri olmaksızın bu emek hiçbir şeydir ve kendisi de öteki işbölümlerini bütünlemek için gereklidir." (Marx, 1992: 32-33).

Marx'ın kapitalizmi analizinde, emek kavramı toplumsal açıdan değerlendirilmiş, emeği yaratan değerin kaynağı toplumun geçirdiği tarihsel süreçler de göz önüne alınarak toplumsal emek biçiminde tanımlanmıştır.

\section{Kapitalist Sınıf İçinde Bölüşüm ve Dolaşım}

Marx'ın analizinde sınıflar arası bölüşüm, dolaşıma gelmeden önce belirlenmiştir. Bu bakımdan dolaşım süreci de üretim süreci temel alınarak açıklanmıştır. Dobb, Ekonomi Politiğin Eleştirisine Katkı'ya yazdığı ön sözde bu durumu şu şekilde değerlendirir;

“....Marx’ın ilgisi değişimi üretim bağlamında açıklamaya odaklanır.... Değişim ilkeleri veya piyasa görünümleri, ancak... toplumun temelinde yer alan bu daha köklü ilişkilerin ifadeleri olarak görüldüğünde anlaşılabilir." (Elson, 2005: 8).

Marx, detaylı dolaşım analizleri sunmuştur. Dolaşımın üretim tarafindan belirlenmiş servetin sadece bir onaylanması olduğunu göstermiştir. Marx’a göre servetin belirleyicisi üretimdir.

Marx'ın dolaşım hakkındaki ayrıntılı görüşleri Kapital'in 2. cildinde bulunabilir. Değer üretimiyle ilgili sermayenin belirli birimlerinin, birbirlerine olan üretken bağımlılığını analiz edilmektedir. Marx bu analizi, bir seri değişim ilişkileri içine oturttuğu, toplumsal üretim ilişkilerini inceleyerek yapmaktadır.

"Birinci aşama: Kapitalist, meta ve emek pazarında alıcı olarak ortaya çıkar; parası metalara dönüşür, ya da $P$-M dolaşımından geçer.

İkinci aşamada: Satın alınan metaların kapitalist tarafindan üretken tüketimi. Burada, o, kapitalist meta üreticisi olarak hareket eder; sermayesi üretim sürecinden geçer. Sonuç, üretimine giren öğelerden daha fazla değer taşıyan bir metadır. 
Üçüncü aşama: Kapitalist, pazara satıcl olarak geri döner; metalar paraya dönüşür, ya da bunlar M-P dolaşımı hareketinden geçer. " (Marx, 2003: 33).

Emeğin sosyal uzmanlaşması içinde, üretim sürecine yeniden başlanması için gerekli olan şey metaların değişim ilişkisine girmesidir. Metaların paraya dönüştürüldüğü böyle bir eylem, saf ticaretin temel anlamı olarak tanımlanabilir. Bu durum Kapital'in 2 ve 3. ciltlerinde detaylı biçimde analiz edilmiştir. $\mathrm{Bu}$ eylemin incelenme nedeni böyle bir dolaşımın, üretim tarafından belirlenmiş servetin ve servetin bölüşümü ile hiçbir şekilde çatışma içinde olmadığının altını çizmektir.

Dolaşım süreci içerisinde yer alan tüccar kapitalistlerin pazarlama ve satışa yönelik faaliyetleri, Marx tarafından değer ve ürün yaratmayan bir emek harcaması biçiminde tespit edilmiştir (Marx, 2006: 246).

Marx'a göre, pazarlama faaliyetleri ve defter tutma ile ilgili işlemlerin, meta üretimi yapan firmanın çalışanları tarafından yapılıp yapılmadığı veya bu işlerin kendilerini sadece bu amaç için kurulmuş olan bağımsız tüccar kapitalistler tarafından yapılıp yapılmadığı, ilgilenmeye değmeyen meselelerdir (Marx, 2003: 122).

Dolaşımda gerçekleşen ise değerin biçiminin değişmesi ve başka bir şeye dönmesidir, bu değerde dolaşıma girmeden önce üretim sürecinde emek tarafından yaratılmıştır.

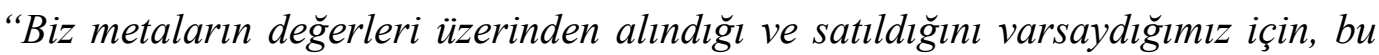
hareketler, yalnızca belli bir değerin, bir biçimden diğer biçime, meta-biçiminden parabiçime ya da para biçimden meta-biçime çevrilmesidir- varlık biçimindeki bir değişmedir." (Marx, 2003: 120).

Meta sermayenin para sermayeye, tüccarlar yolu ile dönüştürülme süreci iki zorunluluğu içerir. Bunlar, kapitalistlerin üreticinin ürününü satın almak için ve emek işe almak için peşin sermayeye sahip olması gerekliliğidir. Meta üreticisi kendisi böyle bir değişimi gerçekleştiriyorsa sadece ikinci öncelik olan emek için ileriye yönelik peşin sermaye gereklidir.

“Tüccar sermayesinin kendisi artı-değer üretmediğine göre, ortalama kâr biçiminde cebe indirdiği artı-değerin, toplam üretken sermaye tarafindan üretilen artıdĕgerin bir kısmı olacă̆ı açıktır”. (Marx, 2006: 249). 
Marx'ın bu süreçte değer ve artık değerin kaynağını nasıl ele aldığı incelenecek olursa, tüccar kapitalist tarafından sadece meta alımı için kullanılan peşin ve genişleyen para sermayesinin karakteri bu incelemede ilk adım olabilir. Tüccar kapitalistin sermayesi kendi başına artık değer üretmediği için, artık değerin transferi şu şekilde gelişmektedir; İlk olarak, tüccar kapitalistin sermayesi sistemin içine çeşitli biçimlerde kâr olarak katılır. Sonuçta üretim fiyatlarını belirlemek için kullanılan ortalama kâr, şu şekilde belirlenir.

“...toplam üretken sermaye tarafindan üretilen toplam kâr ile belirlenmektedir; ama yalnız toplam üretken sermaye üzerinden hesaplanmadı̆̆ gibi olmayıp, yukarda varsayıldı ̆̆ gibi ĕger bu $=900$ ve kâr $=180$ ise, ortalama kâr oranı $=180 / 900=\% 20$ olurdu. Oysa bu, toplam üretken + tüccar sermayesi üzerinden hesaplandığında, 900 üretken ve 100 tüccar sermayesi ile ortalama kâr orant-=180 /1000=\% 18 olur." (Marx, 2006: 252).

İkinci olarak üreticilerin metalarını tüccarlara sattığı üretim fiyatı, bu kâr oranı kullanılarak hesaplanır. Son olarak, tüccar kapitalist ürünü son tüketiciye sattığı zaman fiyatın içine sermayesinin ortalama kârı için bir pay ekler. Bu durum artığın daha önce alınmayan bir parçasının alınmasıdır. Tüccar kapitalist bu kârın kendine ait olduğunu iddia eder.

Farklı yöntemlerle elde edilse de kâr çeşitlerinin yani sanayici kârı yada tüccar kapitalistin kârının hepsi, işçi sınıfından sömürülerek el konulan, artık değerden kaynaklandığıdır. Marx'ın sonucu şudur, genel kâr oranı tüccarın sermayesinden kaynaklanan kârdan dolayı, artık değerden yapılan bir indirim, sanayi sermayesinin kârından yapılan bir indirimdir. Artık, kapitalizm koşulları altında tüccar ve sanayici kapitalist arasında, bu şekilde paylaşılabilir. Marx tarafından bu paylaşımın yasaları da belirlenmiştir.

"Toplam sanayi sermayesinin devir sayısı ne kadar büyük olursa, kâr kitlesi yıllık üretilen artı dĕger kitlesi ve dolayısıyla, diğer koşullar aynı kalmak üzere, kâr oranı o kadar büyük olur. Tüccar sermayesinde durum faklıdır. Tüccar sermayesi için kâr oranı belli bir büyüklüktür ve bu, bir yandan sanayi sermayesi tarafindan üretilen kâr kitlesiyle, öte yandan, toplam tüccar sermayesinin nispi büyüklüğü, bunun üretim ve dolaşım süreçlerinde yatırllmış bulunan toplam sermayeye olan nicel oranı ile belirlenmiştir." (Marx, 2006: 272). 
$\mathrm{Bu}$ analize bakıldığında, tüccar tarafından hazırlanan peşin sermaye, bu altın yada gümüş olabilir, kendi başına emeğin ürettiği bir metadır. Bu nedenle tüccarın kapitalistin sermayesine katılmadan önce, sistemin kâr oranını belirleyen para metanın üretimi sırasında gerçekleşen artık değer, zaten üretken emek tarafından üretilen toplam artık değerin içine dahil edilmiştir. Sonuçta tüccar kapitalist faaliyetinin büyüklüğü toplam artık havuzunu etkilemeden artığın kapitalistler arasındaki bölüşümünü değiştirir.

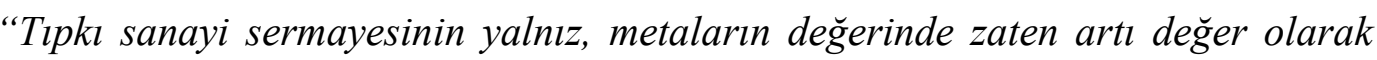
var olan kârları gerçekleştirmesi gibi, tüccar sermayesi de, ancak tüm artı değer yada kârın, sanayi kapitalisti tarafindan metalar için gösterilen fiyatta henüz tamamen gerçekleşmemiş olması nedeniyle bir kâr gerçekleştirir.” (Marx, 2006: 253).

Toplam sermayenin tüccarlar tarafindan kullanılan kısmı, ortalama kâr oranının belirlenmesinde kullanılır. Bu nedenle belli bir üreticinin ve belli bir tüccarın satış fiyatının içine katılır. Fiyatın belirlenmesi için gereken, sanayi sermayenin ve tüccar sermayesinin paylarının sistem içinde verilmesidir. Dolaşım süreci metaların değişim oranlarının içine yapılandırılmıştır. Bu durum bağımsız ve önceden, değişim meydana gelmeden belirlenir.

Dolaşımdan önce, tüccar sermayesinin boyutlarının belirlenmesinin yanında, sermayenin devir sayısını da önceden belirlenmelidir. Eğer tüccar kapitalistler, sermayelerinin her bir devrinde ortalama kâr oranı kazanma hedefindeyseler, tüccarların peşin hazırladıkları sermaye, endüstri sermayesinden daha fazla kâr getirir, bu da genel kâr kanunu ile uyuşmazlık içine düşer. Bu durumu çözmek için Marx şunu ortaya koyar, tüccarlar mallarını fiyatlandırırken, sermayelerinin kaç defa devir yapacağını hesap ederler, böylece yıllık bazda sadece ortalama kâr oranı elde ederler. Bu noktayı Marx şöyle açıklar;

"Yıllık genel kâr oranı \% 15, yatırılan sermaye $100 £$ ise ve bu sermaye yılda bir devir yapıyorsa, tüccar metalarını 115 sterline satacaktır. Ĕger sermayesi yılda beş devir yapacak olursa, 100 sterline satın aldı̆̆ meta-sermayeyi, yılda beş kez 103 sterline, şu halde 500 lük bir meta sermayeyi 515 satacaktır. Bu yatırdı̆̆g 100’lük sermayesi üzerinden, 15'lik aynı yıllık kârı verir.” (Marx, 2006: 273-274).

Sonuçta, üreticiler ve tüccarlar arasındaki artığın uygun şekilde dağılımını etkileyen değişim oranları, dolaşım sürecinin tüm yapısından öncelikli ve varsayımsal olarak sabittir. 
Üreticilerden metaları satın almak amacı ile dolaşımda kullanılan tüccarlar tarafindan ortaya konan sermayeden elde edilen kâr, sadece emeğin üretimle uğraşmasından elde edilen, toplam artığın dağılımını etkilemektedir. Dolaşım sürecindeki emek için kullanılan bu peşin sermayenin, üretici yada tüccar tarafindan ortaya konulmasından bağımsız olarak, bu gelişme toplam artıktaki bir azalmayı temsil eder. Çünkü bu artık emeğe gidecektir fakat gittiği yer üretken bir emek değildir. Artık, bu tip bir üretken olmayan emeği kimin istihdam ettiğine bağlı olarak, bu üretici kapitalist yada tüccar kapitalist olabilir. İstihdam edenin sermayesinde büyüme biçiminde ortaya çıkar. Marx'a göre, metaları paraya dönüştüren emek maliyetleri, sermayenin ek bir yatırımıdır. Özellikle değişken sermayenin bir parçasıdır ve bu gibi bir iş gücünü satın almak için canlı emeğin ürettiği artık değerin bir bölümü kenara ayrılmalıdır. Marx sermayenin yığıldığ alana göre ekonominin yapısı üzerinde de tespitlerde bulunmuştur.

“Üretim ne kadar az gelişmişse, para olarak o kadar fazla servet tüccarların elinde toplanır, yada tüccar servetinin özgül biçimi içerisinde görülür." (Marx, 2006: 287).

Marx, kapitalist süreç içerisinde ve el konulan artığın paylaşımı sırasında tüccar ve sanayici kapitalistlerin sistem içinde geçirdiği evreleri ve değişiklikleri aşağıdaki biçimde özetlemiştir.

“Üçlü bir geçiş söz konusudur. Birincisi, tüccar doğrudan doğruya sanayi kapitalisti haline gelmektedir. Ticaret üzerine kurulmuş zanaatlarda ve özellikle, İtalya'nın 15. Yüzyılda İstanbul'dan getirdiği gibi, dış ülkelerden ham maddesiyle birlikte işçilerinin de getirildiği lüks eşyalar üretilen zanaatlarda bu böyle olur. İkincisi tüccar küçük patronları kendi aracısı haline getirir yada doğrudan doğruya bağımsı üreticiden satın almada bulunarak, sözde onun bağımsızlığına dokunmamış üretim biçimini değiştirmemiş olur. Üçüncüsü sanayici tüccar haline gelir ve doğrudan doğruya toptan piyasa için üretim yapar. (Marx, 2006: 295).

Marx'a göre, maliyetler ve artık arasındaki bölüşüm gerçek piyasa mekanizmasından önce tamamı ile belirlenmiştir. Bu noktada Marx, emek değer teorisi ve bölüşümün üretimde belirlenmesi ile tamamen uyuşan bir dolaşım teorisine sahiptir. Teorisinin meydana gelen değişimlerin, üretim sürecinde önceden belirlendiği üzerine dayandığı görülmektedir. 
Tüccar tarafindan meta ürünün satışı düşünüldüğünde bu durumda Marx’’n söylediği vurgulanacak olursa, "gerçek metaformoz .. (bir metanın) paraya dönmüşüdür." (Marx, 2006: 233). Marx tüccarın satın alma fiyatlarının altına inecek kadar piyasa fiyatlarında bir düşüş olasılığını kabul eder. Piyasa, üretimin belirlediği değeri, kendi belirlediği değerle yer değiştirtir. Üretim ve piyasa değerlerinin farklılı̆̆ kullanım ve değişim değerlerinin birbirleri ile farklı olduğunun da bir göstergesidir. $\mathrm{Bu}$ gerçekleştiğinde tüccar zararla karşılaşır ve bu zararı kendi sermayesinden karşılar.

Marx sermayenin devrini ele alırken devir, veri sermaye için kendisini orijinal formuna dönüştürmesi için gerekli zaman periyodu olarak almaktadır. Marx'ın analizinde tek bir satıcı yada tüccarın bütün sermayesi üç dönem geçirmekte, aktivitesinin yenilenmesi piyasada göründüğü anda meta sermayenin değerinin gerçekleşmesine yada karşılığının alınmasına bağlıdır.

"Herhangi bir kapitalistin bir üretim koluna yatırdı̆̆g tüm sermaye-değer, devresini tamamlayan ne olursa olsun, tekrar kendisini başlangıçtaki biçimi içersinde bulur ve şimdi aynı süreci yineleyebilir. Ĕ̆ger dĕger, kendini sermaye-değer olarak devam ettirecekse ve artı değer yaratacaksa, bunu tekrarlamalıdır. Bir bireysel devre, bir sermayenin hayatında tekrarlanan bir kesimden, böylece bir dönemden başka bir şey değildir... Bir sermaye tarafindan çizilen ve bireysel bir hareket değil devresel süreç amaçlayan devreye, onun devri denir. Bu devrin süresini, üretim zamanı ile dolaşım zamanının toplamı belirler. Bu toplam zaman, sermayenin devir zamanını oluşturur. Tüm sermaye değerin bir devre dönemi ile bir sonraki zaman aralığını, sermayenin yaşam süresindeki devreselliği ya da bir başka deyişle, bir ve aynı sermaye-değerin yenilenme, yinelenme, kendisini genişletme ya da üretim süreci zamanını ölçer.” (Marx, 2003: 142).

$\mathrm{Bu}$ noktada kapitalistin girdiği pozisyon ise piyasa ne sunarsa, sunulanı kabul etmesidir. Çünkü kendini yenilemek zorundadır. Buna karşın piyasa fiyatı kendi başına arz ve talep güçlerine bağlıdır. Belli bir kapitaliste belli bir anda sunulan fiyat sermayeyi yenilemeye ve genişletmeye yeterli olmayabilir. Bu sadece belli bir birim olarak mal satmaya bağlı değildir. Marx’’n sermayenin döngüsünü yapılandırmasındaki analizine göre, bir kapitalistin bütün kaderi her bir dönemde piyasada bulunabilme başarısına bağlıdır. 
Bu yapıda bir kapitalistin hayatta kalabilmesi piyasa durumuna bağlıdır. Kapitalist sistemde piyasada, talebin düşmesinin yada artmasının piyasa şartlarını değiştireceği açıktır. Piyasada oluşan fiyatların gerçek değeri karşılaması arz ve talep güçleri tarafından belirlenir.

"Arz ve talep dengeye geldiğinde ve dolayısıla değişmediklerinde, metanın piyasa fiyatı gerçek değeri olur." (Swezzy, 2007: 57).

Marx, rant ve faizi, bölüşüm meselesinin merkezine oturtmamakta ve hayati önem atfetmemekle beraber kârın, rant ve faize dönüşümünü de analizine dahil etmiştir. Marx’a göre kârın kaynağı artı değer olduğu gibi rant ve faiz de kârın dönüşümünden ortaya çıkmakta ve gene aynı temele dayanmakta, artı değerden kaynaklanmaktadır. Bu noktada temel sınıfsal bölüşüm durumu değişmemekte, kârın rant ve faize dönüşüm süreci içinde kapitalistler tarafından el koyulan artık değer, gene kapitalistler tarafından bölüşülmektedir.

"Sermayesini daha hızlı devrettirmesini sağlayan koşulların kendileri, eğer elverişli bir dükkan yeri gibi satılık şeyler ise, bunun için fazladan bir rant ödeyebilir yani artı kârının bir kısmını toprak rantına çevirebilir.” (Marx, 2006: 276).

"Faiz getiren sermayenin kendisine özgü hareketinde onun hala çözemediği şey nedir.? Kategorileri şunlardır: satın alma, fiyat, nesnelerden ayrllma ve artı değerin burada göründüğü dolaysız biçim; kısacası sermayenin sermaye olarak bir meta haline gelmesi, dolayısıyla satışın borç vermeye ve fiyatın kârdan alınan bir paya dönüşmesi görüngüsü.” (Marx, 2006: 305).

$\mathrm{Bu}$ bölümde birbirine bağlı üretim süreçleri ele alınmış, değerin üretim süreci içinde belirlendiği fikri ile uyuşup uyuşmadığ değerlendirilmiştir. Birbirine bağlı üretim süreçlerinin olduğu yerde, temel olan değişimin gerçek tüketimidir. Satıcılar ve alıcıların gerçek etkileşimi söz konusu ise, böyle bir değişimin değeri belirlemesinin piyasada gerçekleşmesi olasılığı her zaman için vardır, fakat bu değer piyasa tarafından her zaman onaylanmaz. $\mathrm{Bu}$ gerçeğin olduğu yerde sistemin birbirine bağlı karakterinden dolayı, ekonomik ilişkiler sisteminin yeniden üretimi kendi başına tam anlamıyla risk altındadır.

\section{Sosyalizm ve Komünizmde Bölüşüm Prensipleri}

$\mathrm{Bu}$ bölüme kadar, Marx’ın analizi ile kapitalist sistemde bölüşümün nasıl gerçekleştiği açıklanmaya çalışılmıştır. Bu bölümde ise Marx’ın tasarımına göre sosyalizm 
ve komünizmde bölüşümün nasıl olması gerektiğine ilişkin prensipler üzerinde durulacaktır.

Marx kapitalizm sonrası sosyalist ve komünist toplumlarının çerçevesini çizmiştir. Fakat bunun gerçekleşmesi için yaşanması gereken bir süreç vardır. $\mathrm{Bu}$ çerçevede kapitalist üretim tarzının dönüşmesinde ilk gerekli olan diğer tarihsel üretim tarzlarında olduğu gibi kapitalizmin ömrünü doldurmasıdır.

“Kapitalizmden komünizme dönüşüm süreci içinde olan devlet, Marx ve Engels göre her toplumda öyle bir nokta söz konusudur ki bir toplumun üretici güçleri yerleşik mülkiyet ilişkileri ile çatışma içine düşer. Kapitalist toplumda, iki büyük düşman kampa bölünme gün be gün artar, bu iki kamp iki büyük sinıf birbirlerine direkt olarak karşıdırlar (Burjuva ve emek sahipleri) böyle bir çatışma olduğunda sosyal bir devrim gelişir. Öyle ki toplumun bütün ekonomik temelleri politik ve kültürel yapıya paralel bir dönüşüm geçirir. Buna karşın sosyal değişim süreci öyledir ki devrim eski toplum ömrünü doldurmadan ortaya çıkmaz." (Medaline, 1959: 512).

Özetlenecek olursa, toplum devrim sonrası kapitalizm sona erdiğinde bir geçiş dönemi yaşayacaktır. İlk adımda devlet emekçilerin yönetimine girecek ve üretim araçları çalışan sınıfın eline geçecektir. Planlama, piyasa anarşisinin yerini alacak, üretici güçler çok büyük bir biçimde genişleyerek, tam komünizme doğru hareketlenme sağlanmış olacaktır. Tam komünizme ulaşıldığı zaman, kaynakların kıtlığından uzaklaşılırken, üretken güçler bol olacaktır. Bu noktada Marx neye göre üretim yapılacağını da açıklamıştır.

"Sınıf zıtlıklarının ortadan kalktı̆̆ yani hiçbir sınıfın varlı̆̆ının söz konusu olmadığı bir toplumda, kullanma üretim için gerekli minimum tarafindan belirlenmeyecektir. Fakat bir nesnenin üretimi için harcanan zaman, taşıdiğı sosyal faydanin derecesi tarafindan belirlenecektir." (MECW, 2014: 134).

Burada talebin yönlendiriciliğinin belli limitleri söz konusudur, yani bir ürün üretilirken, ürünün diğer ürünlere göre sosyal faydası gözetilmektedir. Üretim bu çerçevede ele alındığında göreceli olarak toplumsal faydası en yüksek olan ürünler toplumda üretilir. Bu noktada meta fetişizmi ortadan kalktığı gibi kapitalizmin neden olduğu kaynakların aşırı kullanımı ve ihtiyacın ötesinde gereksiz kullanımı da gündemden dışı olmaktadır. $\mathrm{Bu}$ yolla toplumsal faydası en yüksek olan kullanım amacı temelinde 
üretilmiş ürünler kıtlık kısıtı dışında üretilebileceklerdir. Bu sürecin bir özelliği de emeğin toplusal yönünü daha hissedilir ve görünür biçim kazanmasıdır.

"Üretim araçlarının emeğin malı haline geldiği sosyalist toplumda, emeğin toplumsal mahiyetini sistemin en açık ve temel özelliği olarak görürüz. ”(Selik, 1982: 66).

Aynı zamanda toplumdaki sınıfsal kurumlar, devlet, parti ve sosyal sinıflar ile yok olacaktır.

“Kaba Komünizm de topluluk demek basitçe emek topluluğu ve ücretlerin eşitliği demektir. Ücretler topluluğun sermayesinden ödenir, topluluğun kendisi evrensel kapitalist olarak düşünülebilinir. Bu ilişkinin her iki tarafi da hayal ürünü olmayan bir evrenselliğe ulaşırlar- emek bir koşul olarak herkesin yerleştirildiği ve sermaye kabul edilmiş evrenselliğe ve toplumun gücü olarak düşünülmelidir." (Marx, 1932: 56).

Ancak bu durum kapitalizmden komünizme doğru olan dönüşümde aşamalı olarak gerçekleşecektir. Burada Engels'e göre devlet ilk aşamada bazı görevler yüklenecektir.

"Devletin kaynă̆ı sınıf çatışması olmasına ră̆men varlı̆̆ını sürdürmek için devlet, düzen yaratır. Sınıf çatışmasını kontrol altına alır ve toplum ortak çıkarlarına hizmet eder; Sınıf çatışması emekçi devrimi tarafindan yok edildiğinde devlet hemen yok olmaz sadece onun baskıcı fonksiyonları ortadan kalkar." (Medaline, 1959: 510).

Kapitalizmdeki devlet, kapitalizmden komünizme geçiş sürecinde varlığını sürdürmesine rağmen bu geçici bir durumdan öteye gitmemekte, devlet yalnızca komünizmin hedeflerine yönelik işlevlere bürünmektedir.

"Devletin gücünün sosyal ilişkilere müdahalesi bir noktadan sonra gereksiz olmaya başlar ve kendi kendini bitirir. Insanların hükümeti yerine şeylerin yönetimi ve üretim sürecinin yönlendirmesi geçer. Devlet ... yok olur.” (Lenin, 1932: 22).

"Devletin ylkılacak, ancak tamamen ortadan kalkmayacak, devletin tam olarak yok olması için, tam bir komünizm gereklidir." (Lenin, 1932: 78).

İnsan egemenliğine, doğasına uygun, özgür bir birey olarak var olacağı komünist sistemde ve yukarıda açıklandığı gibi, yönetimin doğası tamamen tersine dönmektedir. Bu devletli toplumdan devletsiz topluma dönüşüm sadece ve sadece bir evrimleşmenin sonucu olarak ortaya çıkmaktadır. Bu evrimleşmenin doğası da insanın evrimleşmesi ile eş tutulmuştur. 
"Kafa ile yapılan iş ile elle yapılan iş arası bir zıtlık olmadığında. Emek hayatta kalmak için çalışma pozisyonundan, hayatın temel gerekliliğine yükseltildiğinde. Hiçbir birey emeğin iş bölümünün kölesi olamayacak. Birey, saygınlı̆̆l ve değeri için gerekli noktaya doğru geliştirilecektir. En sonunda herkes için özgürlük ve bolluk olacak sadece ikinci aşamada toplum komünist prensipleri hayata geçirebilecektir: "Herkesten yeteneğine göre, herkese de ihtiyacına göre” bu safhada insanlar sosyal hayatın temel kurallarını gözlemlemeye alışacaklardır ve bunlardan devletin ortadan nasıl kalkacă̆ına yönelik yol ise gayet açıktır.” (Medaline, 1959: 517).

Böyle bir noktaya ulaşmak da devletin ideolojik ve kurumsal sınıf farklarını gidermeye yönelik insanı dönüştürmesi (insanı evrimleştirmesi) belki de bu süreçte devletin en önemli fonksiyonu olmakta ve bu sürecin başarısı durumunda otomatik olarak devletin asli görevi son bulmaktadır. Devlet bu bağlamda geçiş sürecide, devrimi evrime dönüştürebildiği zaman fonksiyonlarını yerine getirmekte hem toplumun hem de kendi evrimini tamamlamaktadır. Bireylerin kendilerini, üretim tarzı ve bölüşümde birbirlerine karşılıklı bağımlılık içine sokan emeğin iş bölümü ve bu iş bölümünün yarattığı toplumsal yönlendirmeler yada kapitalist yönlendirmeler bu evrimleşme sırasında ortadan kalkacaktır.

“Emeğin işbölümü amacından saptırılma çerçevesinde emeğin sosyal doğasının ekonomik ifadesidir. Ya da bunun yerine, emek yabancılaşması içinde insan etkinliğinin tek ifadesi olduğundan, hayatın yabancılaşması olarak anlaşılan hayatın ifadesi, emeğin işbölümü emeği amacından saptırma, ileri sürülen yabancılaşmanın emeğin gerçek olması gereken etkinliği olduğu ya da insana özgü bir etkinlik olduğundan başka bir şey değildir. (Marx, 1932: 68).

Marx'ın kuramında, toplum devrime, sosyalizm ve komünizme bir evrimleşme süreci sonunda ulaşmakta, daha önemlisi devrimin bile altında bir bilinçlenme ve evrimleşme yatmaktadır.

"Sosyalizm altında devlet: Gotha programının eleştirisiyle birlikte Marx şu şekilde konuşur; Kominist toplumun iki safhası olduğunu birincisi daha düşük safhası ve ikincisi yada daha yüksek safhast. Zaman geçtikçe birinci safhaya sosyalizm denmeye başland, ikinci safhaya da komünizm. Fakat komünizm terimi birinci safhaya da karşılık gelir." (Medaline, 1959: 515). 
“Şu ana kadar üretim araçlarının kamu mülkü olması ... şunu unutmamalıyı ki bu tam bir komünizm değildir.” (Lenin, 1932: 81).

"Bu terim ne olarak kullanılırsa kullanılsın buna karşın bir sosyal sistemden diğerine kaliteli bir sıçrayış olduktan sonra, yeni toplumun gelişimi evrimsel süreç üzerine yapılanacak bu da daha düşük safhadan daha yüksek safhaya olacak bu olurken de bir sıçrayış olmayacaktır.(sosyalizmden komünizme doğru). Bu komünizmi tamamlamak için yavaş bir evrimleşme süreci ve bu süreçte devlette yavaşça ortadan kalklyor." (Medaline, 1959: 515).

Yukarıda belirtilen gereklilik yeter şart olmadığı gibi toplumda geçiş süreci biçiminde yaşanmaktadır.

“....böyle bir şey bir seferde var olan üretken güçlerin gerekli toplumsal mülkiyet derecesine yükseltmek kadar imkânsızdır. Bu yüzden bütün her şeyiyle olma olasılığı yakın olan emekçi devrimi, var olan toplumu yavaş bir şekilde dönüşürecek ve gerekli miktarda üretim araçları yaratıldı̆̆ı zaman, özel mülkiyet haklarını terk edecektir.” (MECW, 2014. 350).

Kapitalizmin sona ermesi ile metalar ve para ürünlerin üretilmesi ve dağıtılması için kapsamlı bir planlamanın gerektirdiği biçime dönüşecektir (MECW, 2014: 294).

“Marx’ın onayladı̆̆ bir çalışmada, komünist toplumun para ve fiyatları dışladığ görülür, direk yöntemler emek ifadesine ulaşılmada yeterlidir. Kapitalizm'in direk olmayan yöntemleri, buna parasal fiyatları atıfta bulunma da dahildir, direk sosyal üretim ve direk bölüşüm, metaların her türlü değişimini olanaksız kllar, bu nedenle ürünlerin metalara dönüştürülmesini de olanaksızlaştırır. Her durumda toplum içinde, bunların değerlere dönüşümünü olanaksızlaştırır...şöyle ki, buharlı-motor... ya da 100 metre kumaş belli bir miktardır. Bunların değerini herhangi bir şekilde ifade etmek için bir üçüncü ürüne başvurmaya gerek yoktur.” (MECW, 2014: 294).

Kapsamlı plan ve bölüşüm prensipleri insanların ihtiyaçlarını karşılayacak ve toplumun benimsediği yönetim prensibi, her bir bireyin tam ve özgür gelişmesi olacaktır. Plan ise toplam toplumsal olanaklar tarafindan belirlenecektir (MECW, 2014: 294-295).

Sosyalizmden komünizme dönüşümde bunun yanında; Marx aynı zamanda sosyal komünist dünyada milliyetçiliğin yok olacağı, sınıflara üstün gelen, doğru demokrasinin gelişeceğini beklemektedir. 
"Herhangi bir bölüşüm, tüketim araclları ne olursa olsun sadece üretim şartlarının bölüşümünün bir sonucudur. Fakat bu sonraki üretim şartlarının bölüşümü kendi başına üretim tarzının bir özelliğidir. Kapitalist üretim tarzl, örnek olarak, şu gerçek üzerine dayanır; üretimin materyal şartları sermaye ve toprak sahipliği biçiminde işçi olmayanların ellerindedir. Bu esnada yığınlar, sadece üretimin kişisel şartının sahibidir yada emek gücünün sahipleridir. Üretimin öğeleri çok dağılmışsa yada çok bölüşülmüşse, böylece tüketim araçlarının bu günkü bölüşümü otomatik olarak gerçekleşir. Eğer üretimin materyal şartlarl, işçilerin ortak mülkiyetinde ise bu günden farklı olarak tüketim araçlarının benzer bir bölüşümüne yol açar. Gülünç sosyalistler ve bunlardan türeyen bir kısım demokratlar, burjuva ekonomistlerinden aldıklarl, bölüşümün üretim tarzından bağımsız olarak düşünülüşü ve ele alınışı ile sosyalizmi sunarken, onu prensip olarak bölüşümün üzerine yapılandırmıştır. Gerçek ilişki çok uzun zamandır açık şekilde ortaya konmuş olmasına rağmen neden geriye dönüp tekrar edelim?” (MECW, 2014: 87-88).

Marx, üretim tarzının, toplumsal yapının belirleyicisi olarak ortaya çıktığının altını çizmektedir. Marx’ın ideal ya da kapitalizm sonrasında, üretim araçlarının toplumun ortak mülkiyetinde olduğu dönemde, üretimin ve dolayısıyla bölüşümün sosyal bir olgu olduğunu ve bölüşümün üretim sırasında önceden belirlendiğini açıklamaktadır. Beraberinde plana dayalı bir sistem gerektiği ve üretimin önceliğinin sosyal faydası yüksek olan mallara yönetilmesi olduğunu da belirtmektedir. Piyasaların ve paranın bu tip bir toplumda yeri yoktur, kapitalist anlamda değişim de ortadan kalkmıştır. Tek bir seferde özel mülkiyet haklarını ortadan kaldırmak ise mümkün değildir, bu da aşamalı biçimde gerçekleşecektir. $\mathrm{Bu}$ durumda, kapitalizm sonrası bölüşüm aşamalı bir biçimde komünizmin hedeflediği noktaya gelecektir.

"Kapitalizm den çıkan sistemden de ilk aşamada ücret eşitsizliği kabul edilebilinir; fakat daha sonraki aşamalarda (siyasal ve sosyal) eşitlikçi prensiplere başvurabilinir: "Herkes den yeteneğine göre herkese ihtiyacına göre” ve Engels'in ifade ettiği kendisinin ve Marx’ın desteklediği kooperatiflere geçiş dönemine de başvurulabilinir.” (Hollander, 2004: 32).

"Bu toplum kapitalizmden doğduğu için, ihtiyaçlara göre değil de çalışmaya göre belirlenmiş olan, tüketilen nesnelerin dă̆llımındaki adaletsizliği hemen yok edemez." (Medaline, 1959: 516). 
Devrim sonrası, emeğin toplumsal yapısı, eşitliksiz bir yapının eşitlikçi bir yapıya dönüşmüş halidir. Bütün üretim araçlarının topluma ait olduğu bir sistemde emeğin, doğal ya da toplumsal nedenlerden sonucu, ortalamanın üstünde ya da altında bir donanıma sahip olması, yine topluma ait bir olgudur. Bu donanımın ürünü, öyledir ki, verimlilik açısından ortalamanın altı ya da üstü olması ve bütün toplumsal ürünün üretim araçlarında olduğu gibi topluma ait olduğu için verimliliğin ortalamanın üstünde veya altında olması, toplumun olanaklarından elde edildiğinden, bu verim ya da verimsizlikten toplum sorumludur. Kaldı ki, sosyal faydanın yüksek olduğu üretimin bol olduğu bir toplumda insanların, yani kıtlık olgusunun var olmadığı bir yapıda, zaten ihtiyaçları her zaman karşılandığg için istediği kadar üretilenden yararlanma imkânı vardır.

Marx’ta sosyalizmden komünizme geçiş bireyin bir özgürleştirme süreci olarak ortaya konmaktadır. $\mathrm{Bu}$ özgürleşme süreci, bilinçlenme temeli üzerine kurulmuş beraberinde izlenmesi gereken süreç de Marx tarafından ortaya konulmuştur.

Sonsuz ihtiyaçların, kıt kaynakların varlığı ve emeğin iş bölümünün söz konusu olduğu sistemden çıkarak özgürleşmek, tarihsel süreçte evrimleşmenin bir sonucu olarak insanı bağımlı ve sömürüye açık bir toplumsal çerçeveden uzaklaşmasıdır. Bunun yanında insanın bireysel gelişimini sağlamak için özgür hale getirmektir. Bu bir evrimleşme süreci olup evrimleşme sürecinde özel mülkiyet, sınıf kavramı, değer ve bütün diğer kapitalist sisteme ait olan, kapitalist sistemin hak ve özgürlükleri çerçevesinde geçerli olan özgürlük kavramları, yerini gerçek özgürlük olan bireyin bağımsız bir şekilde kendi gelişimini sağlama özgürlüğüne sahip olduğu bir topluma birakacaktır.

\section{Sonuç}

Marx, çalışmasında kapitalist ekonomiyi incelemiş, kapitalist üretim tarzı çerçevesinde bölüşüm eyleminin öznesinin artık değer olduğunun altını çizmiştir. İşçi sınıfının yarattığ 1 artık değerin, kapitalist sınıf tarafından nasıl el koyulduğunu göstererek, sömürüyü ve kapitalizmdeki sınıfsal bölüşüm yasalarını da belirlemiştir. Bu yasaların belirlendiği evreyi üretim olarak göstermiştir.

Dolaşım ve bu yolla artık değerin kapitalist sınıf arasındaki paylaşımını da analizlerine dahil ederken bu önceden belirlenmiş bölüşüm ilişkilerinin, ruhunu değiştirmediğini de göstermiştir. 
Marx, tarihsel ve sosyal analizleri sonucunda insanlığın geçireceği evrimin sonunda devrimlerle varılması gereken noktanın bölüşüm ilişkilerinde artık değerin özne konumundan çıkması olduğunu, bir sınıf tarafından yaratılan artığa başka bir sınıfça el konulmaması durumunda sınıf çatışmalarının olmayacağı ve toplumun sınıfsız olacağını ortaya koymuştur.

Sonuç olarak, Kamu Yönetiminin temel inceleme alanlarında yer alan yoksulluk, geçinme stratejileri, göç, rantların kamuya aktarılması, kentleşme, yatırım, kamu mali yönetimi, devlette ve toplumda dönüşüm, ekonomik-politik araştırmalar gibi alanlarda araştırmalar yapılırken Marx’ın artık değerin “bölüşümü” ve toplumun ve devletin dönüşümü konularındaki teorileri ve görüşleri doğrultusunda araştırmalar yapılırken, bu çalışmanın alt yapı oluşturacağı kanısındayım.

\section{Kaynakça}

Desai, M., 1977. Marksist İktisat Teorisi. İstanbul: Birikim Yayınları.

Elson, D., 2005. Marx’ın Değer Teorisi Neyin Teorisi?. Conatus Çeviri Dergisi 4, Temmuz-Ekim, 4-21.

Hilferding R., 1949. Karl Marx and Close of His System, by Eugen Von BöhmBawerk, by Eugen Von Böhm-Bawerk; and Bawerk's Criticism of Marx. by Rudolf Hilferding, Paul Sweezy (Ed.)., 1966. New York: Kelley.

Hollander, S., 2004. Economic Organization, Distribution and the Equality Issue: The Marx - Engels Perspective. Review of Austrian Economics 17(1), ABI / INFORM Global, 5-35.

Lenin V., 1932. State and Revolutio. New York: International [Online]. Available from: www.marxist.org: http://www.marxist.org/archive/lenin/works/1917/staterev/ [Accessed 21 May 2015].

Marx, K., 1932. The Economic and Philosophical Manuscripts by Karl Marx 1844. First Published 1932, Eng. Translated 1959 [Online]. Available from: www.marxist.org: http://www.marxist.org/archive/marx/works/download/pdf/EconomicPhilosophic-Manuscripts-1844.pdf [Accessed 21 May 2015].

Marx, K., 1992. Ücretli Emek ve Sermaye-Ücret Fiyat ve Kâr. (S. Belli Çev.). Ankara: Kuban Matbaacılık, Sol Yayınları. 
Marx, K., 1998. Artı Değer Teorileri, Birinci Kitap. (Y. Fincancı Çev.). Ankara: Şahin Matbaası, Sol Yayınları.

Marx, K., 2003. Kapital Cilt 2 (5. b.). (A. Bilgi Çev.). Ankara: Kuban Matbaacılık, Sol Yayınları.

Marx, K., 2004. Kapital Cilt 1 (7. b.). (A. Bilgi Çev.). Ankara: Kuban Matbaacılık, Sol Yayınları.

Marx, K., 2006. Kapital Cilt 3 (5. b.). (A. Bilgi Çev.). Ankara: Kuban Matbaacılık, Sol Yayınları.

MECW., 2014. Marx-Engels Collected Works. New York: International Publishers [Online]. Available from: www.marxist.org: http://www.marxist.org/archive/marx/works/cw/volume25-6/index.html [Accessed 21 May 2015].

Medaline R. J., 1959. The Communist Theory of State. American Slavic and East European Review 18(4), 510-525.

Perelman, M., 1999. Marx, Devalorisation and The Theory of Value. Chambridge Journal of Economics (23), 719-728.

Ramirez, M. D., (2007). Marx, Wages, and Cyclical Crises: A Critical Interpretation. Contribution to Political Economy (26), 27-41.

Rühle, O., 2004. Marx'ın Kapitali. İstanbul: Tarih Bilinci Yayınları.

Saad-Filho, A., 2002. The Value of Marx: Political Economy for Contemporary Capitalism. Routledge.

Selik, M., 1974. Marksist Değer Teorisi. Ankara: Doğan Yayınevi.

Sweezy, P., 2007. Kapitalist Gelişme Teorisi. İstanbul: Kalkedon Yayınları. 